\title{
Structural changes in collective accommodation facilities as a component of Ukrainian international tourism
}

\author{
Bohdan Semenko*1 \\ ${ }^{1}$ Taras Shevchenko National University of Kyiv, Ukraine
}

The article presents the structural changes that occurred in the territorial distribution of health and wellness related accommodation units between 2012 and 2017 in Ukraine. It attempts to analyse a specific category of accommodation units as a possible base for the development of international tourism in the country. The factors that could influence their future development at the districts and cities of the oblast (regional) level are revealed. The common factors in providing accommodation facilities were also highlighted through cartographic mapping. One main finding of the paper is a general decrease in the number of accommodation units as well as health and wellness units for the analysed time, at the level of administrative districts and cities of oblast significance of Ukraine. However, some situations where this number increased have been identified.

Key Words: international tourism, accommodation sector, transformation, spatial analysis, hospitality industry.

Article Info: Received: December 12, 2019; Revised: April 30, 2021; Accepted: May 15, 2021; Online: May 31, 2021.

\section{Introduction}

Interpretation of the territorial differences in the development of international tourism in Ukraine, together with the lack of clear governmental steps to ensure

\footnotetext{
"Correspondence address

Address: Taras Shevchenko National University of Kyiv, Kyiv, Ukraine 03022 Prosp.

Akademika Hlushkova 2a.

Phone: +380968851296 | Email: bohdan4311@gmail.com
}

(C)2021 Human Geographies; The authors

(C) $(1)$ This work is licensed under a

Creative Commons Attribution 4.0 International License. DOI:10.5719/hgeo.2021.151.7 
long-term progress, served as the basis for researching the structural changes in the accommodation units as a component of international tourism of the country. This research is helpful for management decisions both in administrative units of rayon level and cities of oblast (regional) significance. The reference period between 2012 and 2017 was particularly chosen since, during this time, significant events took place: the Euro 2012 championship, the military operations in the east of Ukraine: the Autonomous Republic of Crimea and Sevastopol as well as parts of Donetsk and Luhansk regions.

The objectives of this research article are to analyse the territorial distribution of health and wellness related accommodation units and accommodation units, at the level of districts and cities of regional importance during the targeted time spam; to map the transformations during the period under review; to analyse the factors that influence the availability of accommodation facilities as an essential component of international tourism of Ukraine; to discuss the influence of the military conflict on the structural changes of the availability of accommodation facilities in specific administrative units.

Related to this type of accommodation facilities analysis Kuzyshyn (2011) calculated the weighted average coefficient of the development level of tourism infrastructure components for individual regions of Ukraine. The component of this weighted average coefficient includes the coefficient of the availability of accommodation units. The comparison at the level of districts and cities of oblast (regional) significance, provision of accommodation units and the indicator of one-time capacity in the relevant facilities for the period 2015 - 2016 years in terms of one region is revealed in the work of Fil et al. (2017). However, given the short time interval and the lack of analysis of health and wellness related accommodation units in this work, further research in this region is needed.

National and international literature and studies focusing on developing integrated development coefficients, instruments and methods in dealing with tourist development linked to the local potential of regional territorial potential relate to cities and districts of Ukraine mainly discussed by Popova \& Podosenova (2015). A variety of indicators are included and taken into consideration, starting from monuments of nature, cultural and historical heritage objects as part or related to the accommodation infrastructure. Such indicators are part of a coefficient that does not cover all aspects related to the potential of tourism infrastructure when it comes to development. Tourist infrastructure potential Limonina (2007) defined as a general indicator that quantitatively characterizes the development level of the tourism infrastructure in a designated and limited area. The author identified the main elements of infrastructure tourism potential as well as the auxiliary tourism infrastructure and named accommodation facilities among the six main components that relate to the main elements of infrastructural tourism potential. The indicators taking into account accommodation facilities are the number of accommodation units and their 
capacity. The index method was used in that study to establish the state of individual elements of the tourist infrastructure potential. Thus, for each of the allocated elements of the tourist infrastructure potential (main and auxiliary), a corresponding index was calculated. Stepanova (2019) also proposed a methodology, an intermediate stage of which is the calculation of the indicator of the development of the relevant structural element of the tourist infrastructure. Velichkina (2014) disclosed methodological instruments in use for calculating the index of tourism infrastructure. Previous literature on the topic by Cherchyk et al. (2014) carried out the analysis of the institutions of the health-resort industry, an interesting field since it includes significant accommodation facilities. The authors pointed out the uneven distribution of recreational facilities in districts and cities of oblast (regional) significance in a particular region of Ukraine. Butorina (2016) analysed the number of accommodation units and the number of health and wellness related accommodation units and compared the values of the indicators of an individual region to the values of the corresponding indicators in the country as a whole. The author analysed the number of beds in accommodation units between 2013 and 2015. Satyr \& Zadoroshna (2019) analysed, at a regional level, changes in the availability and number of beds of accommodation units and health and wellness related accommodation units for the 2011 - 2017 period. The authors noted that, in the region, the number of establishments that provide hotel services exclusively is increasing. At the same time, the number and share of institutions (as well as beds) that provide additional services (medical, health-improving) is gradually decreasing.

Analysis of the number of accommodation facilities of different types, their dynamics in time and spatial distribution within a region of Ukraine was carried out by Pavlovska \& Onishuk (2015). The number of beds in collective (defined and described in the methodology section) accommodation facilities are also taken into consideration while calculating the capacity use rate of accommodation facilities at the district level without using the indicators of cities of regional significance. The same study takes into account the systematic approach only to find out that lack of relevance since the aim of that study was to provide an analysis at the administrative region level, which includes both districts and cities of oblast (regional) significance.

Buslaeva (2016) analyses the structure of accommodation facilities at the national level in Ukraine. Accommodation facilities of the Carpathian region of Ukraine have been researched by Tsenkler (2016), who noted that the ratio of health and wellness related accommodation units and accommodation units within the Carpathian region is $80 \%$ and $20 \%$, respectively, and $56 \%$ to $44 \%$ at a national level.

Concerning international tourism development, the hotel industry in the Chernivtsy region was investigated by Kyzmina in 2009. Bychko \& Kryl (2011) also analysed the hotel and restaurant infrastructure in the Chernivtsy region. The study concludes on significant findings related to weekend recreational 
tourism, mainly focussed on water resources tourist. This study is limited and does not cover its analysis at the city of oblast (regional) significant level (Novodnistrovsk).

Related to hotel industry development and competitiveness among tourism destinations, some studies touch micro-regional aspects in terms of focusing on disparities (Attila, 2016).

In addition to the hotel industry, several other indicators and aspects that are known to be active as part of the development of tourism infrastructure potential are analysed by countries in studies since the subject is of common ground, by Frent (2019), Rashetnikau (2017), Traskevich (2008, 2017), Iliev (2018), Nicula \& Neagu (2013). Research of the evolution of foreign tourist accommodation by accommodation facilities type at the regional level and overnight stays of foreign tourists in accommodation facilities at the regional level is presented by Frent (2019). Development of the hotel industry at the national and regional levels in Belarus, highlighting the importance of the availability of rooms at the regional level to ensure longer stays and, accordingly, to obtain higher profits, is uncovered by Rashetnikau (2017). The spatial development of the health resort industry at the regional level in Belarus and the importance of the availability of such infrastructure for the effective functioning of the industry is revealed by Traskevich (2008). The competitiveness of the health-resort industry in Belarus and the process of constructing the medical and health tourism infrastructure is exposed by Traskevich (2017). The author also highlights that precisely the formation of medical and health tourism infrastructure has become the primary condition for specialized organizations to enter the tourism market. The evolutionary changes at a regional level of Macedonia and the territorial disparities in tourism development by highlighting active and underdeveloped areas and the differences between them, including in the distribution of accommodation facilities, are approached by Iliev (2018). We find that aspects on which these works are concentrated are relevant to be taken into account by our paper since Belarus has similar recreational resources to the northern regions of Ukraine. As in Ukraine, Belarus has a significant extensive network of accommodation facilities. With the dissolution of the USSR, both countries faced the problem of functioning country-owned institutions. Macedonia, a country which in the past was part of Yugoslavia, the experience of developing the tourism infrastructure of this country is helpful for Ukraine since military conflict continued in Macedonia in 2001. Some administrative units of Romania and some administrative units of Ukraine have similar recreational resources. The Carpathian Mountains pass through the territory of both countries, and both countries also have the Black Sea coast, so the analysis of the development of the international tourism of Romania will be useful for Ukraine.

As a result, this paper develops the following working hypotheses:

- At the Ukrainian national level, there are significant disparities in rates of availability in both health and wellness related accommodation units and accommodation units, 
- The distribution of health and wellness related accommodation units and accommodation units in Ukraine tend to thin out (the number of administrative units in which they respectively are represented has decreased).

- On overall accommodation facility availability indicator has declined at a national level, but it has increased in some administrative districts and cities of oblast (regional) significance.

\section{Methodology}

The research was conducted at the level of administrative districts (rayons) and cities of oblast (regional) significance of Ukraine. Researching the transformation of the availability of accommodation facilities was divided into an analysis of two components:

1) accommodation units;

2) health and wellness related accommodation units,

using the statistical information submitted by the State Statistics Service of Ukraine (2019), which includes, among other things, a complete list of the classification of accommodation facilities. According to report form № 1-KZR (richna) "Zvit pro diyalnist kolektivnogo zasoby rozmishyvannya" accommodation facilities include:

1) Accommodation units: hotel; motel; hostel; campsite; agro-hotel; dormitory for visitors; tourist base, mountain student summer camp and other places for temporary accommodation.

2) Health and wellness related accommodation units, which include: sanitarium (or in Eastern Europe is called sanatorium); children's sanitarium (sanatorium); boarding houses with treatment; children's recreation facility wich operate year-round; child centre; sanitarium-preventorium (sanatoriumpreventorium); balneological hospital; mud bath, balneo-mud therapy centre (including children's); resthouse; boarding guest house; recreation base; other facilities of recreation (except for tourism bases); recreational institution of onetwo days stay. In order to avoid collisions in the terminology, the term sanatorium, which is identical to sanitarium, will be used.

Hotels are accommodation facilities consisting of six rooms or more and provide hotel services for temporary accommodation with mandatory service. A motel is an accommodation unit located outside the city along a motorway, usually in a one-, two-story building or in a part of a building with a separate entrance, which has facilities for parking and car maintenance. Hostel (youth hotel) - a hotel in which rooms are usually located along a corridor or block system and has conditions for self-catering and hygiene amenities on the floor or in the block; can organize meals in a restaurant establishment. Camping - accommodation unit in a fenced area, where accommodation is provided in cottages and (or) bungalows and (or) provide space for tents, caravans and caravans-houses. The territory is equipped with public sanitary facilities. 
Agrohotel is a hotel located in the countryside, which has conditions for agricultural activities during recreation.

Health and wellness related accommodation units- accommodation units that can be non for profit, have a single management, provide a minimum of hotel services (except for daily bedding), do not necessarily have rooms, but can have housing units or collective sleeping quarters and, in addition to accommodation, perform any other function (for example, treatment, rehabilitation, social assistance, transportation) according to State Statistics Service of Ukraine, (2012).

Several maps were developed to analyse the structural changes in accommodation facilities as an essential component of the country's international tourism: the number of accommodation units in 2012 and 2017; the number of health and wellness related accommodation units in 2012 and 2017. The maps were realized using the software QGIS.

Ukraine consists of 24 oblasts, the Autonomous Republic of Crimea, the cities of Kyiv and Sevastopol. A city gets the status of oblast significance by parliamentarian resolution. It is worth noting that this status is usually granted to cities of industrial importance, or are essential transport hubs, or have great potential for development. Cities of oblast significance are separate administrative-territorial units that are not subordinated to administrative districts and are not part of administrative districts. To fully cover the territory of Ukraine, this article also includes the cities of Kyiv and Sevastopol, which have a special status. The article also mentions the Chernobyl exclusion zone (formerly called the thirty-kilometre exclusion zone). The population was forcibly evicted from the exclusion zone; however, tourist trips are carried out in it with permission from a special public authority that manages it.

The study analyses the transformations that took place during the period between 2012 - 2017 years, as these years were crucial for the development of international tourism. In 2012, the Euro 2012 football tournament was held in Ukraine, and in 2017 Ukraine received a visa-free regime with the EU countries, which served as an impetus for the further development of outbound tourism. This study is also very important, given that since 2014, military conflict has continued in the country, and part of the territory is temporarily occupied. The following methods, which allowed to exemplify the changes that took place over the years, were used: comparison, time slices, cartographic. Given the existing territorial imbalances in service provision by accommodation facilities, the research at district and cities of regional significance level is the most optimal.

The state of a particular element of the tourist accommodation infrastructure (in the context of accommodation units) was established using the index method. Applying the index method allows for the determination of territorial disparities. The number of accommodation units and their capacity were used as indicators that characterize accommodation units (Limonina, 2007):

$$
I=\frac{\left(\frac{a}{A}+\frac{b}{B}\right)}{2}
$$


Where,

$I$ - index of accommodation units of the respective administrative unit,

$a$ - number of accommodation units in the administrative unit,

$A$ - average number of accommodation units per one administrative unit,

$b$ - number of beds in accommodation units of the administrative unit,

$B$ - average number of beds in accommodation units per one administrative unit.

\section{Results}

To provide quality services to international tourists, it is important that the potential tourist has a choice of accommodation (with the appropriate level of service). In discussing accommodation units accessed by international tourism, it is worth recalling that in 2012 the leading positions in terms of numbers belonged to Kyiv, Yalta and Feodosia. Odesa was next, somewhat lagging behind these cities, ahead of Alushta by more than 30 units. in 2012, among the first ten leading administrative units, 5 were from the Autonomous Republic of Crimea. Distribution of accommodation units in 2012 represented in Figure 1.

Among the top ten leaders in terms of the number of accommodation units in 2017, all administrative units, except Kharkiv, were able to increase their total number of units over a five-year period. The leading positions in terms of the number of accommodation units in 2017 were held by Kyiv and Odesa.

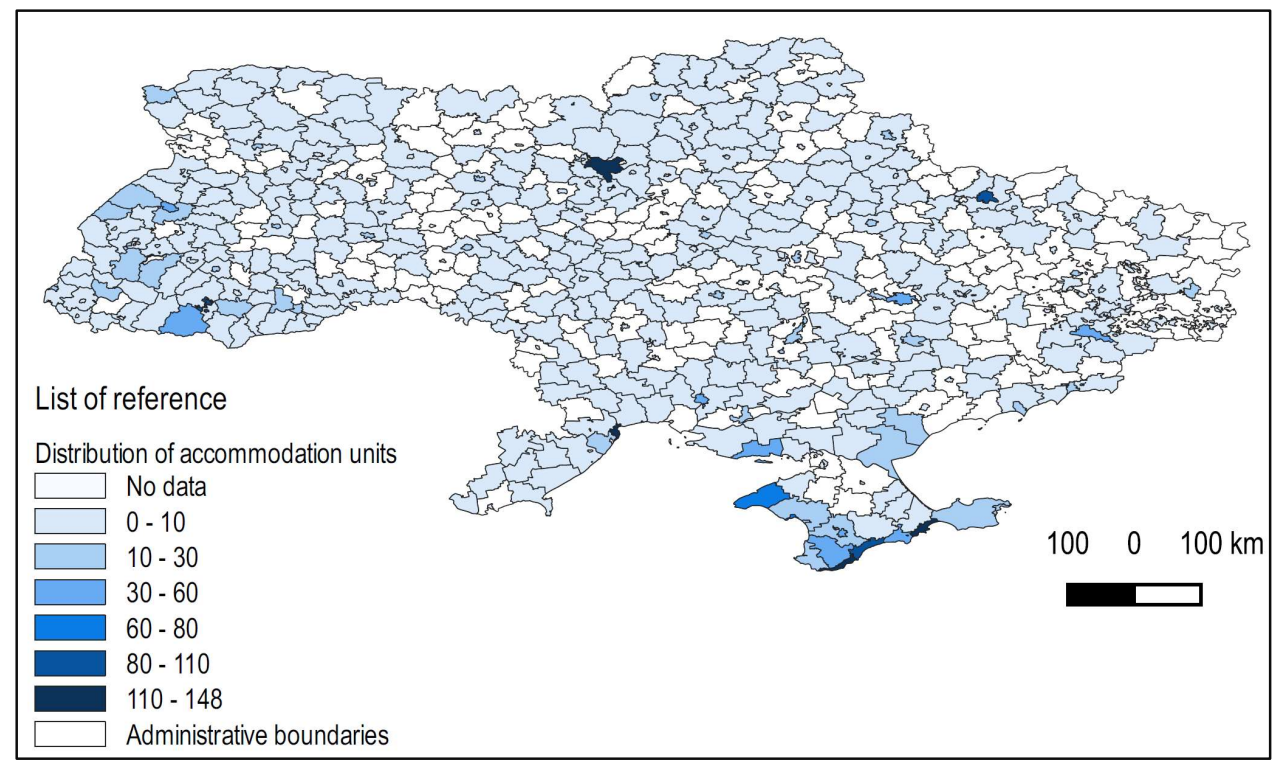

Figure 1. Distribution of accommodation units in administrative districts (rayons) and cities of oblast significance of Ukraine in 2012. 


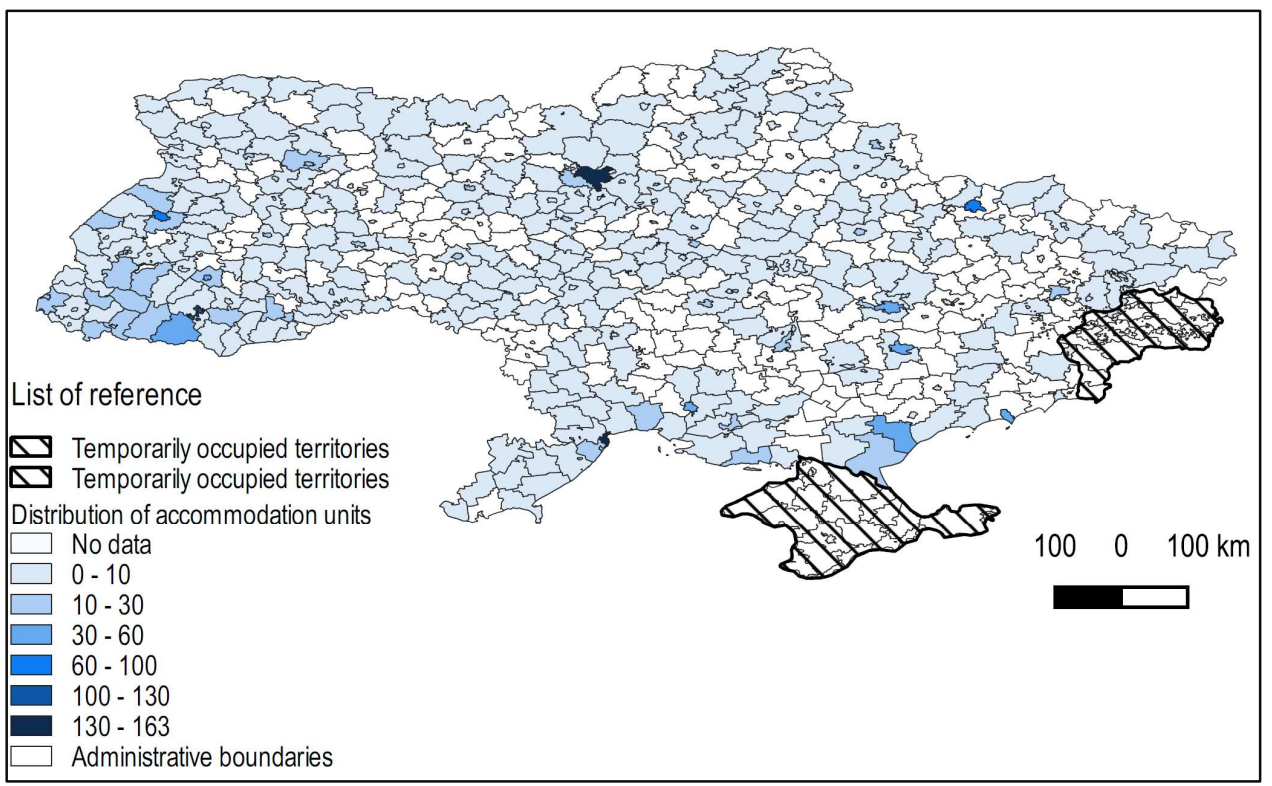

Figure 2. Distribution of accommodation units in administrative districts (rayons) and cities of oblast significance of Ukraine in 2017.

The small number of accommodation units is a deterrent to the further development of international tourism in Slavutych. Unlike health and wellness related accommodation units, accommodation units were concentrated in the largest cities of Ukraine. They were also concentrated in many administrative units of the Autonomous Republic of Crimea, in Yaremcha, Skadovsk and Rahivskiy districts. Noteworthy is the fact that the total availability of accommodation units in administrative units that have access to the Sea of Azov was significantly lower than the total availability of health and wellness related accommodation units in these administrative units, respectively (Figure 2).

The development of international tourism in the Chernobyl Exclusion Zone has shown a positive trend in the studied period. At the same time, neither Ivankiv nor Vyshgorod districts, nor the city of Slavutych, have enough accommodation units to meet the needs of international tourism in these administrative units, which results in the loss of a considerable part of the funds, as foreign tourists often prefer to stay overnight in Kyiv. Thus, these administrative units need to allocate funds as quickly as possible for the construction of accommodation units. Particular attention should be paid to the availability of accommodation units in a significant number of administrative units of the Odesa region, which was extremely low in 2017 in areas with significant tourist potential, in particular in Belgorod-Dnestrovsky, Kiliysky, Reni districts, as well as in the Bolgrad and Kominternovsky (Liman) districts.

The low level of availability of hotels and similar accommodation in the city of oblast significance Chop and Irshava district in 2017 diminishes the other 
competitive advantages of these administrative units, like the low value of the communication index (index of transport infrastructure development) of the city of Chop compared to other administrative units of the Zakarpattya region and the resource and recreational potential of Irshava district respectively. The extremely negative impact of the military conflict on the development of international tourism in the Donetsk region is visible mainly in Krasniy Liman in 2017. It is worth noting that near the Krasno-Lymansky district is the Holy Dormition Svyatogorsk Lavra (monastery), which is important for the development of international tourism throughout the region. The existing sizeable industrial potential of Mariupol was not used even at one-third of its capabilities for the needs of international tourism after the outbreak of the military conflict. Also worth mentioning is that the town of Zhovti Vody has several important industrial sites that can attract a large number of foreign tourists. However, the low level of availability of accommodation units translates into a lack of potential alternative accommodation choices and is often a deterrent in the travel decision.

In 2017 the top twenty administrative units contained $42,88 \%$ of the number of accommodation units, decreasing from $43,86 \%$ in 2012. And, compared to 2012, the first twenty administrative units, by the number of accommodation units in the total share, have changed. In 2017 Kyiv, Kharkiv, Odesa, Dnipropetrovsk, Zaporishya and Lviv gathered 22,3\% of the total number of accommodation units in the country. In 2012 accommodation units were located in 464 administrative units, whereas in 2017 , they were located in only 400 administrative units.

The temporary occupation of a significant part of Ukraine's territory in the east and south in 2014 made the development of the infrastructure in those territories impossible. The increase in the number of accommodation units in Zaporishya contributed, among other things, to the development of infrastructure projects in the city, including reconstruction of the international airport, establishing close communication between local authorities, systemforming enterprises, as well as moving a large number of highly qualified specialists from the temporarily occupied territories of Donetsk and Luhansk regions to Zaporishya, which increased the city's economy and in turn increased the number of accommodation units for the needs of international tourism.

In 2012, Kyiv had the highest value of this index, and Odesa also registered a typically high index. In 2012 the concentration of high values of this index in some administrative units of the Autonomous Republic of Crimea was to be expected, in particular in such administrative units as Yalta, Feodosiya, Alushta and Yevpatoriya (Figure 3).

In 2017, in addition to Kyiv, which, as in 2012, had the highest value of this index, Odesa and Yaremcha had high values of this index, respectively. Among other administrative units, it is also worth mentioning Lviv, Kharkiv and Dnipropetrovsk, which in 2017 were among the top ten leaders in terms of this index (Figure 4). 


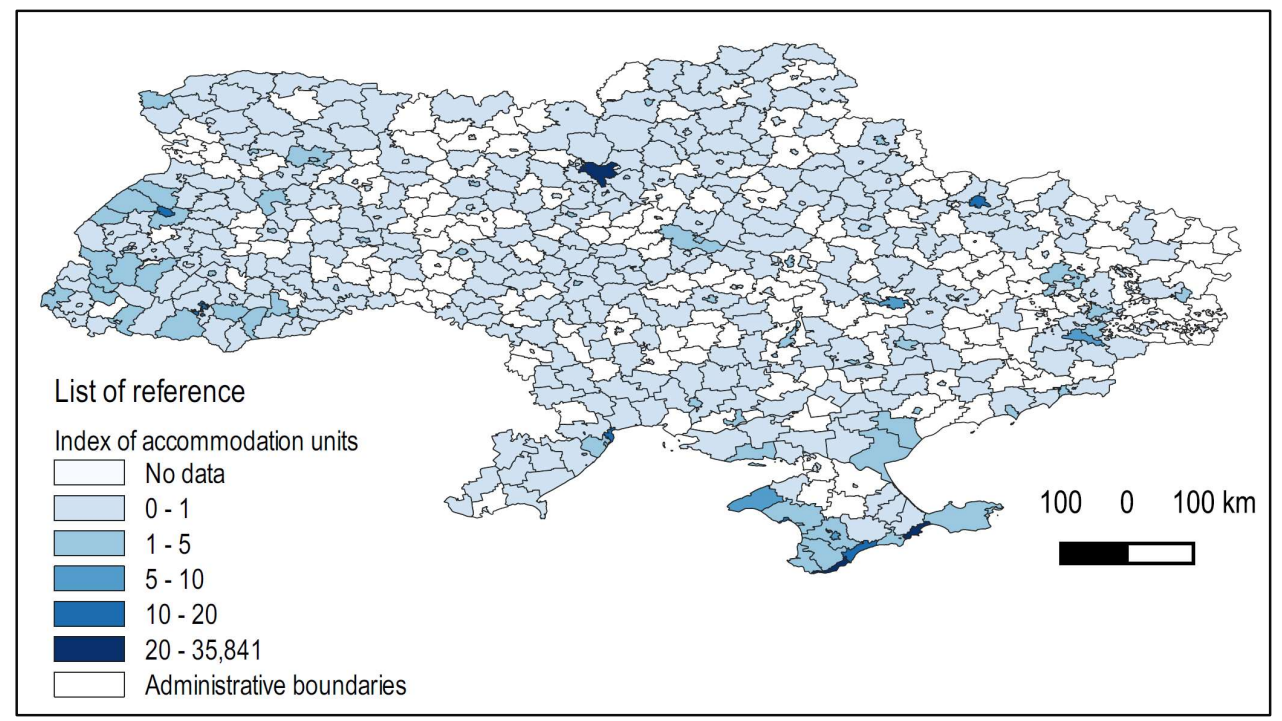

Figure 3. Index of accommodation units in 2012.

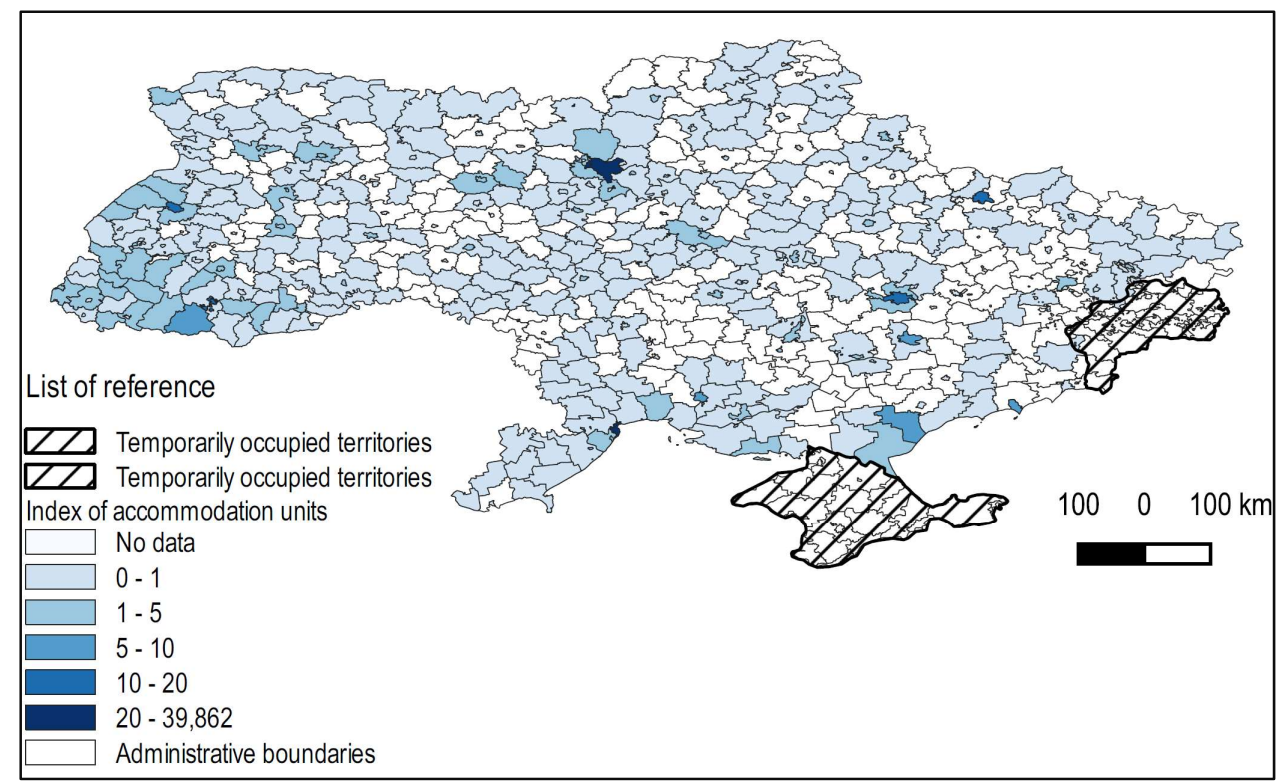

Figure 4. Index of accommodation units in 2017.

In 2012, the leading position in terms of the number of health and wellness related accommodation units in Ukraine was occupied by the Berezansky district of the Mykolaiv region, with 146 sanatoriums operating in the area, and the settlements - Koblevo and Rybakivka were the leading centres of health and wellness tourism in the area are located. In 2017, the number of health and wellness related accommodation units in the district decreased slightly, but the district still occupies one of the leading positions in terms of the number of such establishments. 
A significant concentration of health and wellness related accommodation units was primarily for administrative units with access to the sea. At the same time, a deficient level of availability of health and wellness related accommodation units was characteristic for administrative units bordering the Republic of Belarus. It is noteworthy that the low level of availability of health and wellness related accommodation units in the administrative units located in the northern part of the Odesa region and the many administrative units bordering the Republic of Moldova. Given the tourism resources available in the Reni district, the availability of health and wellness related accommodation units in the district should have been at a higher level (Figure 5).

One of the most significant structural changes that occurred as a result of the 2014 military conflict was that the level of health and wellness related accommodation units in the Mangus district of the Donetsk region sharply reduced, so if in 2012 there were 140 such units in the region, in 2017 there were only 31 . If the military conflict continues in the east, as well as the economic blockade of the city of Mariupol, there will be an increase of the negative effects in the development of international tourism, which has characterized the Mangus district for the last 5 years (Figure 6).

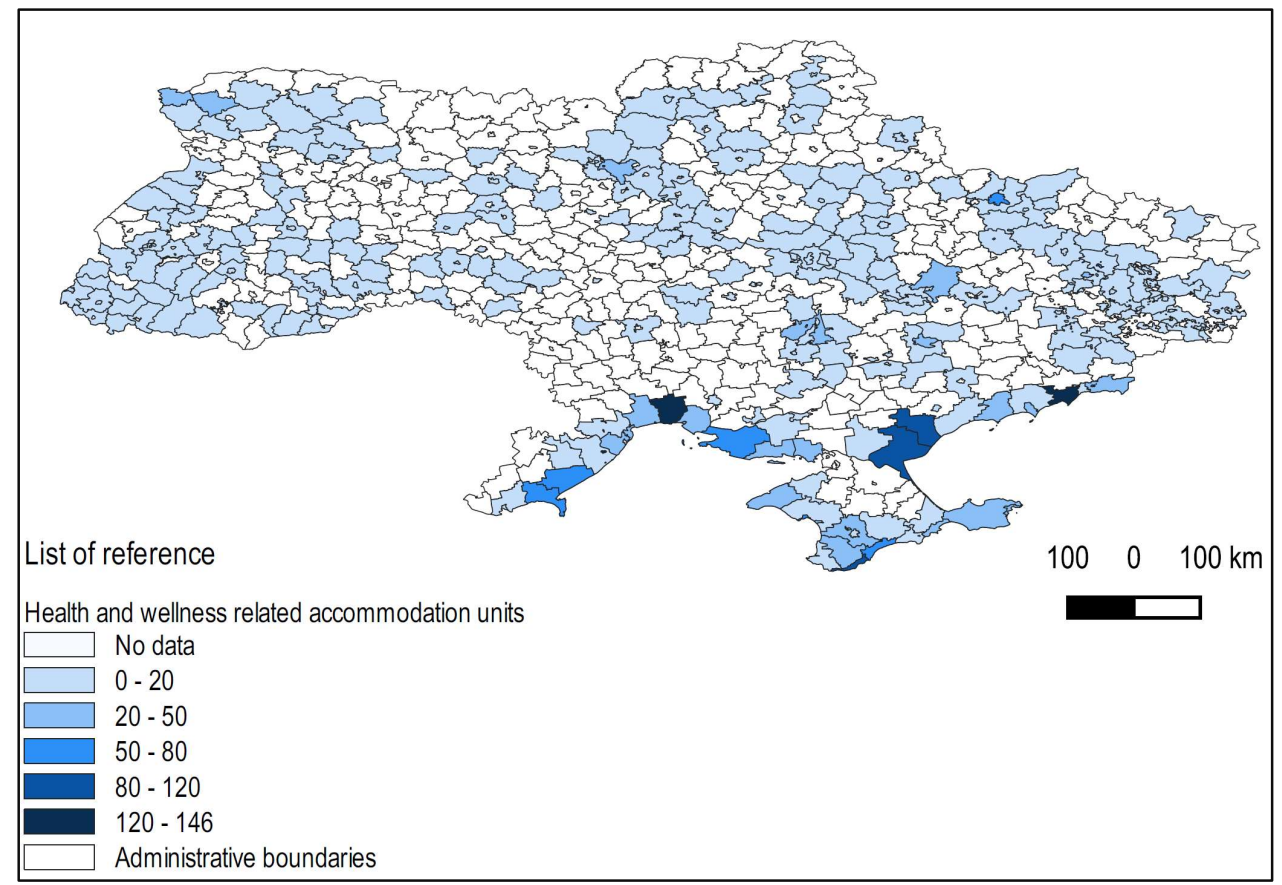

Figure 5. Distribution of health and wellness related accommodation units in administrative districts (rayons) and cities of oblast significance of Ukraine in 2012. 


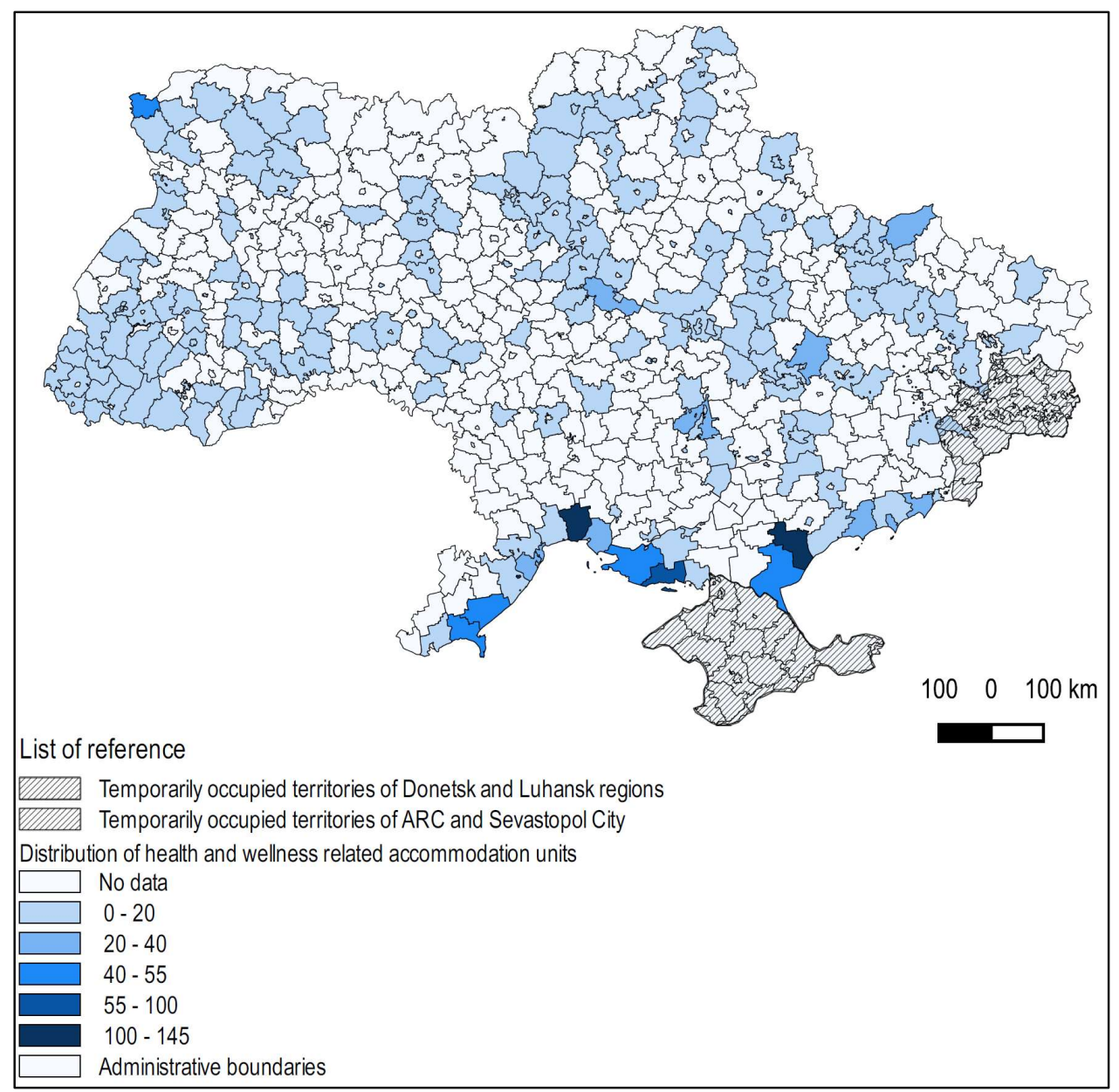

Figure 6. Distribution of health and wellness related accommodation units in administrative districts (rayons) and cities of oblast significance of Ukraine in 2017.

Belgorod-Dnestrovsky also holds the leading position in terms of providing health and wellness related accommodation units. The available natural tourism resources make it possible to further develop international tourism in the city. At the same time, attention should be drawn to the low level of development of the transport systems in the southern part of the Odesa region as a whole. An important condition for the development of international tourism in the city will be effectively promoting the city as an important centre of health and wellness tourism in international tourist exhibitions and forums. In absolute values, the number of health and wellness related accommodation units in the city decreased slightly compared to 2012 (136 and 128, respectively) but still exceeds more than twice the values of Skadovsk district (128 and 56 respectively in 2017).

Significant changes have taken place over the last five years in the Yakimovsky district of the Zaporizhzhya region. In 2017, there were 145 units in the district, while in 2012, there were only 105 . This allowed the district to occupy a leading 
position in terms of this indicator among all administrative districts and cities of oblast significance in Ukraine. The existing natural tourist resources of the area allow the development of health and wellness tourism in the future while increasing the budget revenues from foreign tourists.

Of all the material losses suffered due to the occupation of the Autonomous Republic of Crimea, a considerable part also accounts for the specialized means of accommodation of that area. In 2012, 100 health and wellness related accommodation units were operating in Yalta alone. The negative dynamics in the number of health and wellness related accommodation units over the past 5 years have been observed in the Genichesky district of Kherson region. So, if in 2012 there were 92 enterprises operating in the district, in 2017, this indicator decreased more than twice. Also, the disruption in the power lines that took place in 2015 hinders the development of inbound tourism in the area. Comparing the number of health and wellness related accommodation units, one should pay attention to the city of Krasny Liman, which in 2012 occupied a leading position among administrative units of rayon level and cities of oblast significance in the availability of health and wellness related accommodation units. The high value of the index of transport infrastructure, together with the availability of significant tourist natural resources, are essential factors for developing international tourism in the city. However, the proximity of the military contact line is a deterrent.

Currently, the potential of Southern Bessarabia as an area with significant natural tourism resources for the development of international tourism is still not fully unlock. Compared to 2012, the number of enterprises in the Kiliyskiy district decreased by almost a third in 2017. Similar trends occurred in the Tatarbunar district, where the number of units decreased by more than a third and in 2017 was only 43 units. One of the main areas of development of the region should be cruise tourism and the development of transport infrastructure, which in turn would lessen the effects of the difficult socio-economic situation in the region.

The structural changes that have been taking place in Odessa for a long time deserve special attention. Thus, during the 5 years analyzed, the number of health and wellness related accommodation units in the city decreased by more than $40 \%$; these changes are a consequence of the unsuccessful policy of the state to develop the spa and resort economy in the region. Unfortunately, the city was strongly affected by privatization in all areas, which despite public resistance, led to a change in the designated use of a large number of health and wellness related accommodation units. It is evident that the state did not effectively develop the sanatorium and health resort enterprises as a part of the national economy, resulting in the loss of a number of units that were important for the city on the international stage. Thus, local authorities need to allocate funds as quickly as possible for the construction or improvement of health and wellness related accommodation units, which can provide a high level of service for international tourists. 
In 2012 the highest number of providers of health and wellness related accommodation units was registered by the Shatsk district, which was able to improve this indicator, and in 2017 it increased to 46 units, remaining the highest figure in the Western part of the country, even ahead of the city of Truskavets. Significant positive changes are also seen in the Skadovsk district. This is explained by the reorientation of tourist flows to the Kherson region (until 2014, a large part of them accounted for the Autonomous Republic of Crimea).

The high level of health and wellness related accommodation units is also seen in the Ovidiopolsky district, with the total number of units in 2017 of 37. Availability of health and wellness related accommodation units in the northern border-straddling administrative units was at a very low level in 2017, and a significant number of such units were concentrated in the first twenty administrative units. Specifically, the first twenty administrative units held 60,69\% of the country's health and wellness related accommodation units, compared with 2012 when they only held 50,25\%.

The reduced number of health and wellness related accommodation units in Kyiv and Kharkiv is explained by the fact that a large number of the facilities in these cities were explicitly created to serve tourists during the Euro 2012 tournament of football, after which there was no need for them.

In 2017, a high concentration of health and wellness related accommodation units was not in the largest cities by population but in some of the administrative units that have outlets to the sea. Among the top 15 administrative units by the number of health and wellness related accommodation units, 13 have an outlet to the sea, which points to the territorial disparities in the distribution of such facilities in the country. If in 2012 the health and wellness related accommodation units were located in 310 administrative units, in 2017, they were located in 232 administrative units.

\section{Discussions}

Between the years 2012 and 2017, only five of the top fifty administrative units (top fifty in 2012) in terms of the number of health and wellness related accommodation units in Ukraine increased the value of this indicator. Only three of these top fifty administrative units were a part of the regions through which the Carpathian Mountains pass (Tryskavets, Tyachivskiy district, Yaremcha). In 2012 eleven of them were located in the Autonomous Republic of Crimea; also the city of Sevastopol was in the top fifty leaders, and thirty-one of them had access to the sea coast. The concentration of a large number of health and wellness related accommodation units in 2012 in Sevastopol and administrative units located in the Autonomous Republic of Crimea is explained by the very high level 
of provision of recreational resources of the Autonomous Republic of Crimea and the city of Sevastopol.

At the same time, among the mentioned thirty-one administrative units, only two of them increased their number of health and wellness related accommodation units in 2017 compared to 2012 (Yakimivskiy and Skadovsky districts). The increase in this value in such a small number of administrative units is explained primarily by the conflict in eastern Ukraine and the occupation of the Autonomous Republic of Crimea. The military and political tensions have strongly repulsed potential investors. As for Yakimivskiy and Skadovskiy districts, both are centres of the development of children's tourism, and in 2017 they are at a considerable distance from the line of military conflict. However, in 2017 both districts were located at a relatively short distance from the Autonomous Republic of Crimea.

The situation in Zakarpattya region is worth discussing as in 2012 the health and wellness related accommodation units were located among the cities of regional value (Ushgorod and Mukachevo), and in 2017 none of the cities of regional significance held a single health and wellness related accommodation units. Given the available recreational resources of the region, these changes are extremely negative, especially considering that cities of regional significance often have better transport accessibility and the region itself is one of the few regions of the country where practically each of the administrative unit of the region has a high level of endowment with recreational tourism resources.

Significant differences in the availability of two categories of accommodation facilities were observed in 2012. In such administrative units as Rahivskiy district and Chernivtsy, there were no fewer than thirty accommodation units in each of them, whereas the number of health and wellness related accommodation units district did not exceed two in each of them. The city Chernivtsi is developing business and cognitive tourism, which explains the significant number of accommodation units in the city. In the Rakhivskiy district, a significant number of accommodation units is due to the development of ski tourism.

The same goes for the Starovishivskiy district of the Volyn region, Kalanchatskiy and Tatarbynarsky districts. The Tatarbynarsky district had more than fifty-five health and wellness related accommodation units in 2012, while there were no more than two accommodation units. The Starovishivskiy district of the Volyn region and Kalanchatskiy district had more than twenty health and wellness related accommodation units each and no more than two accommodation units.

In 2017 significant differences in the availability of two categories of accommodation facilities were observed in particular in such administrative units as Ivano-Frankivsk, Poltava, which had more than twenty accommodation units each and no more than two health and wellness related accommodation units each. In Poltava and Ivano-Frankivsk are developing business and cultural 
tourism; they are the centres of the respective regions. The average length of stay of tourists in these cities compared to administrative units specializing primarily in medical tourism is less.

Discrepancies were observed in the Vovchanskiy district of the Kharkiv region, Kiliyskiy, Novomoskovskiy, Krivorizkiy districts: with each having more than twenty health and wellness related accommodation units and no more than two accommodation units. It should be pointed out that significant disparities in the availability of two categories of accommodation facilities, both in 2012 and in 2017, were observed in some of the Black Sea and some Pryazovia administrative units.

\section{Conclusions}

The structural changes that occurred between 2012 and 2017 in the availability of health and wellness related accommodation units and accommodation units were analysed. The differences are clear and are influenced by a series of factors, among which an important one is the influence of the military conflict affecting Ukraine since 2014.

The analysis was conducted at the level of districts and cities of oblast (regional) importance, and on all accounts, the number of accommodation units as well as in the arrangement of health and wellness related accommodation units, at the level of administrative districts and cities of oblast significance of Ukraine. Overall the distribution of accommodation units as well as in the arrangement of health and wellness related accommodation units shows a thinning out of resources. The availability of health and wellness related accommodation units in the northern border-straddling administrative units was at a very low level for the analysed period. In 2017 twenty administrative units incorporated the majority of health and wellness related accommodation units, and these were concentrated not in the largest cities by population but in some of the administrative units that have an outlet to the sea.

If in 2012 the highest values of the index of accommodation units were characteristic for Kyiv, Odesa and some administrative units of the Autonomous Republic of Crimea, in 2017 the most significant values of this index in addition to Kyiv and Odesa, respectively, were also observed in Yaremcha. Accommodation units were present in larger numbers than health and wellness related accommodation units both in 2012 and in 2017. In 2017 accommodation units, as opposed to health and wellness related accommodation units, were heavily concentrated in the largest cities by population.

There are administrative districts and cities of oblast significance where the indicator of the availability of accommodation facilities had increased during the analysed period. At the same time, in our opinion, attracting domestic funds from 
domestic investors for the development of international tourism infrastructure is a top priority since this greatly increases the benefits of the state compared to attracting funds from foreign investors.

\section{References}

Attila, A.T. (2016), "The Impact of the Hotel Industry on the Competitiveness of Tourism Destinations in Hungary", Journal of Competitiveness, vol. 8, no. 4, p. 85 - 104.

Buslaeva, G. (2016), "Current status and development trends of collective accommodation facilities in Ukraine", Scientific Bulletin of KhSU, vol. 18, no. 1, p. $74-79$.

Butorina, V. (2016), "Problems and conditions of realization of the potential of the hospitality industry in Ukraine and Khmelnytsky region", Eastern Europe: economy, business and management, vol. 3 p. 159-163.

Bychko, Zh.I. and Krul, H.Ya. (2011), "Spatial analysis of development of hotel and restaurant infrastructure of tourism in the Chernivetska oblast", Geography and tourism, vol. 11, p. $34-41$.

Cherchyk, L., Yerko, I., Kolenda, N. and Mishenko, O. (2014), The current state of development of the tourist and recreational complex of the Volyn region, Lesia Ukrainka East European National University, Lutsk.

Fil, M., Holiavka, V. and Koropetska T. (2017), "Status and prospects of accommodation of hotel establishments in the Lviv region for 2016", Scientific Messenger LNUVMB, vol. 19, no. 81, p. 45-48.

Frent, C. (2019), "Inbound tourism in Romania: a profile at regional level based on accommodation statistics", Journal of tourism - studies and research in tourism, vol. 28.

Iliev, D. (2018), "Regional inequalities and contemporary problems in regional tourism development: a case of Macedonia", Anatolia - An International Journal of Tourism and Hospitality Research, vol. 29, no. 3, p. 368-378.

Kuzyshyn, A.V. (2011), "The modern level of formation of the tourist infrastructure in the western areas of Ukraine", Scientific notes of TNPU, Series: Geography, vol. 2, p. 122-128.

Kyzmina, V. (2009), "Hotel industry in the context of the development of international tourism in the Chernivtsi region", Bulletin of Chernivtsi Trade and Economic Institute. Economic sciences, vol. 3, p. 199 - 206.

Limonina, I.G. (2007), "Regional specificities of infrastructure tourism potential of Leningradskaya region", Vestnik of Sankt Petersburg University, vol.7, no. 2, p. 117-127.

Nicula, V. and Neagu, R. (2013), "Evolution of Tourist Accommodation Structures in Romanian's Developing Regions in the Context of New Challenges at European Level", Procedia Economics and Finance, vol. 6, p. 542 - 549. 
Pavlovska, T. and Onishuk, I. (2015), "Collective accommodation in the Volyn region: current state and dynamics of development", International Scientific journal "Scientific Review", vol. 5, p. 26 - 40.

Popova, O.B. and Podosenova, I.A. (2015), "Tourist-infrastructural potential of the Orenburg oblast", Vestnik of Orenburg State University, no. 1, vol. 176, p. 167 173.

Rashetnikau, D. (2017), "Current trends and problems of the hospitality industry development of the Republic of Belarus", Scientific works of the Republican Institute of Higher Education, vol. 16, p. 386 - 394.

Satyr, L. and Zadoroshna, R. (2019), "Statistical analysis of development trends tourist activity in Kyiv region", Clustering of the tourism industry - a significant lever in the cultural, educational and economic development of Kyiv oblast Conference, Kyiv regional institute of postgraduate education of pedagogical staff, p. 79-92, 12 April 2020, shorturl.at/wzKLV.

State Statistics Service of Ukraine (2012), Rozyasnennya shodo zapovneyya formi dershavnogo statistichnogo spostereshennya № 1-KZR (richna) "Zvit pro diyalnist kolektionogo zasoby rozmishyvannya”, 12 May 2020, shorturl.at/iCILX.

State Statistics Service of Ukraine (2019), Responses of the request of Semenka Bohdana Volodymyrovycha to the functional body of State Statistics Service of Ukraine, 12 May 2020, http://www.ukrstat.gov.ua

Stepanova, S.V. (2019), "Territorial disproportions of the tourism infrastructure location in the Republic of Karelia", Izvestiya DVFU. Economics and Management, no. 3, p. 89-97.

Traskevich, A.G. (2008), "Regional development of the sanatorium tourism segment in Belarus", Pskov Regional Journal, vol. 6, p. 132 - 141.

Traskevich, A.G. (2017), "Sanatorium segment competitiveness analysis for the tourism industry in Belarus", Medical News, vol. 7.

Tsenkler, N. (2016), "Background recreational activation European integration processes in Carpathian region", Global and national problems of economy, vol. 9 p. $522-525$.

Velichkina, A.V. (2014), "The assessment of the regional tourism infrastructure development", Economic and Social Changes: Facts, Trends, Forecast, no. 2, p. 193 202. 